Boston University School of Law

Scholarly Commons at Boston University School of Law

Faculty Scholarship

$4-2-2012$

\title{
Economic Depreciation, Accrual Taxation, and the Samuelson Theorem: An Essay on the Structure of Capital Income Taxation
}

Theodore S. Sims

Boston Univeristy School of Law

Follow this and additional works at: https://scholarship.law.bu.edu/faculty_scholarship

Part of the Law and Economics Commons, and the Tax Law Commons

\section{Recommended Citation}

Theodore S. Sims, Economic Depreciation, Accrual Taxation, and the Samuelson Theorem: An Essay on the Structure of Capital Income Taxation, in No. 12-16 Boston University School of Law, Law and Economics Research Paper (2012).

Available at: https://scholarship.law.bu.edu/faculty_scholarship/433

This Article is brought to you for free and open access by Scholarly Commons at Boston University School of Law. It has been accepted for inclusion in Faculty Scholarship by an authorized administrator of Scholarly Commons at Boston University School of Law. For more information, please contact lawlessa@bu.edu. 


\title{
BU School of Law
}

\section{ECONOMIC DEPRECIATION, ACCRUAL TAXATION, AND THE SAMUELSON THEOREM: An Essay ON THE StRUctuRE of CAPITAL InCOME TAXATION}

\author{
Boston University School of Law Working Paper No. 12-16 \\ (March 30, 2012) \\ Revision of April 2, 2012
}

Theodore S. Sims

This paper can be downloaded without charge at:

http://www.bu.edu/law/faculty/scholarship/workingpapers/2012.html\# 
Electronic copy available at: http://ssrn.com/abstract=2031533 
Original Version: March 21, 2010

Revision of April 2, 2012

Economic Depreciation, Accrual Taxation, and the Samuelson Theorem: An Essay on the Structure of Capital Income Taxation

Theodore S. Sims*

Samuelson (1964) showed that an income tax with an allowance for "economic" depreciation leads to asset valuations that are independent of their holders' marginal rates of tax. The tax system is then "neutral," in the sense that assets have the same value to all, irrespective of whether or at what rate they are taxed. In this essay I illustrate and show formally that taxation of cash flow minus an allowance for economic depreciation leads to the taxation of value as it accrues. That is, economic depreciation and pure accrual taxation are exactly equivalent. I suggest also that the form of "depreciation" allowance that gives rise to this result has implications for neutral taxation of capital income that extend beyond depreciation as such, and may help to improve our understanding of some of the historically more vexing details of property income taxation.

*Professor of Law, Boston University School of Law. Thanks to John Adney, Ben Damsky, Alan Feld, David Garlock, Daniel Halperin, James S. Halpern, George Mundstock, David Walker, and Alvin Warren for comments on preliminary versions. Thanks also to Robert Guth, Patrick Jiang, Alexander Mackinger, and Sanil Padiyedathu for research assistance along the way. The usual disclaimer applies. 

Economic Depreciation, Accrual Taxation, and the Samuelson Theorem:

April 2, 2012 An Essay on the Structure of Capital Income Taxation

\section{Introduction}

Most academic tax lawyers and public finance economists, and at least some tax practitioners, are acquainted with the finding of Paul Samuelson's 1964 paper that asset valuations under a periodic income tax are independent of the holder's marginal tax rate only if depreciation allowances are "economic," in the sense that they reflect actual changes in asset values over time. ${ }^{1}$ Economic depreciation gives rise to an important form of "neutrality": the tax system does not distort asset values by causing them to vary with their holders' marginal rates. In principle at least, an income tax that used economic depreciation would lead to depreciable assets being valued the same by all holders, and would moderate the complications generated under existing law by tax-induced trading of assets among holders facing different marginal rates. ${ }^{2}$

Implementing a system of economic depreciation might very well be impracticable. In practice, allowing economic depreciation in computing taxable income is (and more or less always has been) some distance from what we actually do. ${ }^{3}$ For that reason Samuelson's insight is viewed

1 Samuelson, Tax Deductibility of Economic Depreciation to Insure Invariant Valuations, 72 J. Pol. Econ. 604 (1964); see also Fane, Neutral Taxation Under Uncertainty, 33 J. Pub. Econ. 95 (1987); Lyon, Invariant Valuation When Tax Rates Change Over Time, 98 J. Pol. Econ. 433 (1990). I use the term "income tax" to denote a personal tax that extends to changes in wealth as they accrue, and refer to an idealized version of that tax as a "pure accrual tax." The terminology is in common use. E.g,, Andrews, A Consumption-Type or Cash Flow Personal Income Tax, 87 Harv. L. Rev. 1113 (1974), though on occasion it elicits controversy. E.g., Strnad, Taxation of Income From Capital: A Theoretical Reappraisal, 37 Stan. L. Rev. 1023 (1985); Kaplow \& Warren, An Income Tax by Any Other Name -- A Reply to Professor Strnad, 38 Stan. L. Rev. 399 (1986). See infra note 43.

2 See, e.g., Sims, Debt, Accelerated Depreciation, and the Tale of a Teakettle: Tax-Shelter Abuse Reconsidered, 42 U.C.L.A. L. Rev. 263, 264-279 (1994). Miller, Debt and Taxes, 32 J. Fin. 261 (1977). Though it is getting ahead of the story, the history of the taxation of debt, which between 1954 and 1981 vacillated between too lenient and too onerous before settling on (approximately) just right, is instructive. For a summary of the history see. e.g., Sims, Long Term Debt, The Term Structure of Interest and the Case for Accrual Taxation, 47 Tax L. Rev. 313, 319-326 (1992).

3 Prior to the Economic Recovery Tax Act of 1981, the Office of Industrial Economics of the U.S. Treasury Office of Tax Policy was devoted largely to the statistical study of parameters needed to estimate economic depreciation rates. With the shift to a formulary "accelerated cost recovery system" ("ACRS") in lieu of depreciation, such official efforts were largely discontinued and the OIE was shut down. With the modification of the ACRS depreciation system in 1986 ("MACRS"), a new Depreciation Analysis Division was established within the Office of Tax Policy. Useful accounts of U.S. income tax treatment of depreciation may be found in Brazell, Lowell, Dworin, and Walsh, A History of Federal Tax Depreciation Policy, OTA Paper 64 (1989); U.S. Treasury, Report to the Congress on Depreciation Recovery Period and Methods (2000); see also Hulten \& Wykoff, The Measurement of Economic Depreciation, in Depreciation Inflation $\&$ the Taxation of Income From Capital (1981); Hulten, Getting Economic Depreciation Almost Right (2008) (available at http://econweb.umd.edu/ hulten/WebPageFiles/Getting\%20Economic\%20Depreciation\%20Almost\%20Right.pdf)]. To some extent the current Alternative Depreciation System, used in computing alternative minimum taxable income, is intended to be closer to economic depreciation than MACRS. Income taxation aside, estimation of depreciation of the U.S. capital stock is of importance in determining national income. See, e.g., Fraumeni, The Measurement of Depreciation in the National Income and Product Accounts, July 1997 Survey of Current Business 7. 
as of largely theoretical interest, a state of affairs that is abetted by the fact that its derivation is couched in continuous time mathematics that are not especially accessible to tax lawyers. Consequently, despite the fact that the mechanics underlying Samuelson's insight are independently of interest, they are not very well understood. In particular, although at least some students of taxation share the intuition, alluded to in Samuelson's original paper, that there is an important connection between deductibility of economic depreciation and accrual taxation of capital income, as implemented most conspicuously with respect to original discount debt by $\S 1272$ (a) of the Internal Revenue Code, it deserves to be better understood that those two are not just closely related but equivalent. A central objective of this paper is to make that analytic equivalence explicit. ${ }^{4}$

The endeavor begins with three simple financial assets, which I introduce in Part II. In Part III(A), I use those assets first to illustrate that, some appearances involving cash method taxpayers to the contrary notwithstanding, we use accrual taxation with respect to debt more generally than $\S 1272$ (a) alone would suggest. Part III(B) then illustrates the relationship between what might at least plausibly be regarded as "depreciation" of one of those assets and accrual taxation of the returns to that asset. In Part IV I introduce a fourth, somewhat more arbitrarily chosen investment, intended to exemplify the irregular sort of sequence of cash flows from a "depreciable" asset; and, in that more arbitrary setting, provide a second illustration of the relationship between economic depreciation and accrual taxation. From there I articulate the relationship generally, using an abstract discrete-time representation of an asset. I return in Part V to the simplest example from Part

\footnotetext{
4 I recall one distinguished academic tax lawyer observing that he "always thinks of the treatment of original issue discount as sort of "reverse depreciation'." And though I haven't actually heard it, I can readily imagine one of his colleagues asserting that "if we know that economic depreciation is correct, and think that accrual taxation is too, then there must be an intimate connection between the two." Nevertheless, I take as informal corroboration of the unverifiable claim that this connection is less well understood than it deserves to be that even recent editions of that wonderful collection of insights into the U.S. income tax, Chirelstein, Federal Income Taxation (11th ed. 2009) (hereinafter Chirelstein), while carefully developing (as it has since its earliest incarnations) both the accrual of interest on a level payment installment loan and sinking fund depreciation, as well as that the two illustrate essentially the same phenomenon, stops well short of saying that economic depreciation and accrual taxation are generally equivalent. Id. $\S \S 2.02,6.09$. Pedagogic observations on the topic tend to be inexact in describing the relationship between the use of economic depreciation and the measurement of income. E.g., Graetz \& Schenk, Federal Income Taxation 337-338 \& n.1 (6th ed. 2009).

One observer who does take the equivalence as pretty much apodictic, to the point of treating Samuelson's original article as though it were expressly about accrual taxation rather than economic depreciation, is Jeff Strnad. E, $g$, Strnad, Tax Timing and the Haig-Simons Ideal: A Rejoinder to Professor Popkin, 62 Ind.L. J. 73, 76-77 \& nn. 12 \& 15 (1986); Strnad, Periodicity and Accretion, 99 Yale L.J. 1817, 1854-1857 (1990). All that Samuelson actually said, however, was that his "formula for depreciation is algebraic. When $\mathrm{V}^{\prime}(\mathrm{t})$ is positive rather than negative the deduction for depreciation becomes an inclusion of so-called capital appreciation." (605-06). See infra Part V. That stops well short of saying that economic depreciation leads to accrual taxation in the typical setting in which depreciation is subtracted from cash flow in determining taxable income.
} 
II to illustrate the Samuelson theorem itself. Building on the analysis, I conclude in Part VI with the observation that the scope for application of the Samuelson theorem is broader than is commonly supposed. I suggest, in particular, that the relevance of the form of "depreciation" allowance that emerges from Samuelson's analysis extends beyond the matter of depreciation to many (if not most) aspects of capital income taxation. As such, at least to the extent that "neutral" taxation is viewed as desirable in principle, ${ }^{5}$ it may offer a fresh lens through which to examine some of the historically more problematic aspects of capital income taxation.

This started out as, and to an important extent remains, a pedagogically motivated endeavor. The relationship between depreciation and capital income taxation that is formalized in Part IV, though developed for present purposes from a study of Samuelson's 1964 paper, can be found in the work of Irving Fisher, and to some extent elsewhere in the economics literature. ${ }^{6}$ Along the way I have developed in a companion piece a constructive discrete time proof of the Samuelson theorem that formalizes an intuitive explanation of the operation of that theorem articulated by Strnad. ${ }^{7}$ But the account of depreciation and capital income taxation at the center of the exposition here may be intuitively understood by experienced participants in this field. Nevertheless, for those in that category let me conclude this introduction with a question. If you were asked by a student to define "economic depreciation," your immediate answer almost surely would be "Depreciation that reflects the actual decline in asset values." If asked for more detail you would

5 At least at a marginal rate different from 0 . Neutral taxation in this same sense would also exist with a cash-flow type tax, under which all asset costs are expensed; but expensing is generally equivalent to exempting the asset returns from tax. E.g., Brown, Business-Income Taxation and Investment Incentives, in Income, Employment and Public Policy: Essays in Honor of Alvin H. Hansen 309-310 (1948), reprinted in Readings in the Economics of Taxation (1959); Andrews, supra note 1, at 1126-28.

6 Irving Fisher, The Nature of Capital and Income, Ch. 14, especially 236-38 (1906); Fisher, Income in Theory and Income Taxation in Practice, 5 Econometrica 1, 6 (1937). See, e.g., Gravelle, The Capital Cost Recovery System and the Corporate Income Tax, C.R.S. Report No. 79-230E (1979), 28-32. In formal terms the relationship is also implicit in Samuelson, as developed by Stiglitz, The Corporation Tax, 5 J Pub. Econ. 303, 305-306 (1976); see also Sims, Environmental "Remediation" Expenses and a Natural Interpretation of the Capitalization Requirement, 47 Nat'1 Tax J. 703, 705 (1994) (hereafter "Sims, Natural Capitalization"); Keifer, The Tax Treatment of a Reverse Investment, 26 Tax Notes 925 (1985).

7 Sims, Economic Depreciation and Invariant Valuation: A Constructive Proof of the Samuelson Theorem (February 26, 2012, available at http://ssrn.com/abstract=2006557). Strnad's explanation is that the impact of taxes on the return to an asset and on discounting offset one other, neutralizing the impact of taxes on the return. See Strnad, Tax Timing and the Haig-Simons Ideal: A Rejoinder to Professor Popkin, 62 Ind.L. J. 73, 77 \& n. 16 (1986); Strnad, Periodicity and Accretion, 99 Yale L.J. 1817, 1853-54 (1990); Interview with James F. Strnad, 14 ABA Tax Section Newsletter 9 , 10 (1994). His illustration actually does not involve depreciation; it is a perpetual annuity that accrues and pays $C$ each period, whose pre-tax value (at interest rate $r$ ) is $C / r$. If each accrual is taxed at rate $t$, and if (assuming interest is tax deductible) the after-tax discount rate is $r^{*}(1-t)$, then the after tax discounted value is just $C^{*}(1-t) / r^{*}(1-t)=C / r$. See infra Part V; Appendix A-II. 
probably turn to an example of "sinking fund" depreciation of the sort illustrated in eleven (and one-half) editions of Chirelstein. But suppose you were pressed, and asked to be both more comprehensive and more precise. What would your next move be? If you are secure in the knowledge that you have a one-line answer to that question stop here. If, however, you find the question intriguing you may find it of interest to read on. I won't detain you for long.

II. The Assets

My three primitives consist of two bank accounts and a bond. First,

The Bond (Asset 1). The bond (depicted in Panel A of Table 1) is assumed to have a redemption price of $\$ 10,000$, to be of seven years' maturity, and to make one $\$ 1,000$ coupon payment annually at the close of each year. ${ }^{8}$ If the market yield for instruments of comparable risk and maturity is 10 percent, the bond should sell at par, that is, for an issue price of $\$ 10,000$. This is plain vanilla, non-discount debt.

The conventional account of income taxation of the instrument is straightforward. Each annual coupon is currently includible in income, as "interest," irrespective of the method of accounting the holder generally is on. ${ }^{9}$ If it is accrual, the $\$ 1,000$ obligation accrues each year; if it is cash, the accrued obligation is also actually paid. Either way $\$ 1,000$ is taxed. The $\$ 10,000$ received on surrender at maturity is an "amount realized" on disposition, and after subtracting the holder's $\$ 10,000$ adjusted basis (her cost) there is no realized gain. Hence, the original purchase price (the "principal") is received back without tax, while the amounts received in excess of that (the "payments," of "interest") are taxed to the holder on "receipt".

One more thing about the bond. If 10 percent remains the market yield on comparable instruments, its value should remain constant at $\$ 10,000$. Each year the bond would offer coupon interest at a market rate, and prospective holders would continue to value it at par. So in that (unrealistic) scenario investors would value the bond at $\$ 10,000$ up until the date at which it could be surrendered for that amount. ${ }^{10}$

8 As one simplification I assume that the coupon is paid annually; semi-annual coupons are the norm. E.g., Sharpe, Alexander \& Bailey, Investments 350 (6th ed. 1999) (hereafter "SAB"). The example also ignores possible complications due to variations in interest rates, and in particular to the impact of the "term structure" of interest rates on the pricing of the bond. See infra note 10 .

9 Treasury Regulations, $§ 1.446-1(\mathrm{c})$.

10 With constant interest rates the value would in fact fluctuate predictably over the course of each period, rising (by as much as $\$ 1,000$ ) as each period's interest accrued, then falling back to $\$ 10,000$ as each periodic coupon was paid. See Fisher, The Nature of Capital and Income 206-208 (1906). In practice, if the instrument is transferred between payment dates the transferor pays the redemption price plus interest accrued to the date of transfer. E.g., SAB at 351 . As 
Account 2: Compound Interest. The second asset consists of $\$ 5,131.58$ deposited in a bank that pays 10 percent interest, compounded annually. The growth in the account over seven years is illustrated in Table 1, Panel B. Where, as in this example, the interest earned each year is left on deposit, the interest credited increases each year by an amount equal to interest on the interest added to the account during the immediately preceding year. In each year, then, the account earns interest on the balance, augmented by interest credited in all preceding years, so that the effect of compounding at a constant stated rate is to (a) increase the amount credited as interest each year, at (b) an increasing rate. In the first year the interest credited (in round numbers) is $\$ 513$, in the second it grows by $\$ 51$ to $\$ 564$, in the third it grows by another $\$ 57$ to $\$ 621$, and so on, increasing by $\$ 83$ to $\$ 909$ in year 7 , bringing the account balance from $\$ 9,091$ to $\$ 10,000$.

The operational centerpiece of compounding is that the interest credited each year is the product of the stated interest rate and the account balance at the end of the preceding year. So if the balance -- its value -- at the end of any year $k$ is denoted by $V_{k}$, the interest credited at rate $r$ in the next year $(k+1)$ is just

$$
r * V_{k}
$$

Consequently, the account balance at the end of that next year $\left(\mathrm{V}_{k+1}\right)$ is the sum of the two, or

$$
V_{k+1}=V_{k}+r * V_{k}=V_{k} *(1+r) .
$$

Since this is true in every period, it follows recursively that each $\mathrm{V}_{k}$ is given by the "future value function"

$$
V_{k}=V_{0} *(1+r)^{k}, \quad(k=0,1,2, \ldots)
$$

where $V_{0}$ was the initial deposit to the account. ${ }^{11}$

Account 3: Compound Interest, Level Withdrawals: As illustrated in Table 1, Panel C, $\$ 4,868.42$ is deposited to Account 3, which is likewise credited with interest at 10 percent, so that

\footnotetext{
a rule, the matter is usually more complex, principally because of the term structure of interest rates, but the account in the text will suffice for our purposes. E.g., SAB at 112-14, 119-20; Brealy, Myers \& Allen, Principles of Corporate Finance 57-59, 629-31 (8th ed. 2006) (hereafter "BMA"). See also Bankman \& Klein, Accurate Taxation of Long-Term Debt: Taking Into Account the Term Structure of Interest, 44 Tax L. Rev. 335 (1989); Sims, Long Term Debt, The Term Structure of Interest and the Case for Accrual Taxation, 47 Tax L. Rev. 313 (1992).

11 E.g., Bodie, Merton \& Cleeton, Financial Economics 108-114 (2d ed. 2009) (hereafter "BMC"). The assumption of annual compounding is for convenience, and for consistency and simplicity in developing the examples. In practice financial institutions now compound daily, or essentially continuously, and if need be we can think of the account as compounding daily over a 365 day year at 0.000261 ( 0.026 percent). In continuous time the growth of the account is given by the exponential function $e^{\mathrm{rt}}$, where $t$ (in lieu of $k$ ) denotes the continuous passage of time. Id at 114 . That the account balance grows, at an increasing rate, reflects that both the first and second derivatives of $e^{\mathrm{rt}}$ are positive.
} 
$\$ 486.84$ is credited to the Account at the end of year 1 , bringing the balance to $\$ 5,355.26$. Now, however, the holder is assumed to withdraw exactly $\$ 1,000$ at the end of each year, so that the first year's withdrawal reduces the balance to $\$ 4,355.26$. Interest continues to be credited on a compound basis, in that it is credited at the stated rate applied to the actual account balance, but now each year that balance is both augmented by interest and reduced by the scheduled withdrawal. Since, moreover, the first year's withdrawal exceeds the interest credited that year, by the end of year 1 the balance in Account 3 has been reduced. So the interest credited in year 2 is also reduced; and, with a constant withdrawal, the account balance will again be reduced in year 2, this time by more than it was in year 1 . In that fashion Account 3 is depleted, at an increasing rate, by (again in round numbers) $\$ 513$ at the end of year 1, \$564 in year 2, and so on, eventually exhausting the account, in this case by the end of year $7 .{ }^{12}$

Income taxation of both accounts is also straightforward. The holder is taxed currently on the interest credited, whether or not actually withdrawn. Interest credited to a cash-method holder of Account 2 is included on the conventional understanding that it is "constructively" (even if not actually) "received." ${ }^{13}$ But the presence of taxation in the absence of actual receipt suggests that accrual is a sufficient condition for taxation. ${ }^{14}$ If so, then in every period the entire Account 2 balance has been subjected to tax (and thus is effectively "tax paid"), so that withdrawals -- actual "receipts" from the account -- are not an occasion for imposing tax. In the case of Account 3, the interest both accrues and is paid each year, since given our assumptions the amount withdrawn in the first (and therefore in each subsequent) year exceeds the interest credited during the year. ${ }^{15}$ But whether regarded as taxed because of accrual alone or accrual plus withdrawal, the account balance (apart from the interest credited and withdrawn) is in any event tax-paid; and it is understood that each annual withdrawal is not taxed beyond the amount credited as interest that year. Hence, accrual of interest is not merely sufficient (as in Account 2) but necessary to taxation of Account 3. Withdrawal alone doesn't suffice. That is, the systematic withdrawals ("receipts")

\footnotetext{
12 Although deployed for a specific purpose here, Account 3 captures the basic economics of a variety of common financial transactions, including in particular the accrual of interest and amortization schedule of any level-payment fully amortized loan, such as a home mortgage, automobile loan, or revolving consumer loan, as well as periodic payments under an annuity contract.

13 Income Tax Regulations $§ 1.451-2$.

14 On the other side of the transaction -- interest accrued but not paid by cash method borrowers -- there are cases that hold otherwise. See infra note 25.

15 See supra, text at note 12 .
} 
from Account 3 do not themselves trigger taxation. It is periodic crediting of interest that does. In effect, then, though conventionally thought to be achieved in the case of Account 2 via "constructive" receipt by a cash-method holder, the interest credited to both accounts is taxed as it accrues, in that accrual is both a necessary and sufficient condition for inclusion. In both cases the amount taxed in each year $(k+1)$ is just $r^{*} V_{k}$, as given by (1), although, in the case of Account $3, V_{k}$ reflects both the interest credited during, and the withdrawal at the end of, year $k$. III. Implications

(A) Taxation of Conventional Debt: Cash or Accrual? ${ }^{16}$ Accounts 2 and 3 clearly were constructed so that together the two replicate the Bond. That can be seen from Table 1, Panel D, in which the balances in, interest accrued during, and withdrawals each year from the two accounts have been added. In toto, they are initially endowed with $\$ 10,000$, the purchase price of the bond. As with the bond, the sum of the balances in the two accounts at the end of every period is also $\$ 10,000$, since Account 2 increases in value each year while (taking into account the periodic withdrawals) Account 3 declines by exactly the same amount. ${ }^{17}$ Since, moreover, each account earns interest at 10 percent, the sum of the amounts periodically credited to the combined accounts is $\$ 1,000$ each year, that being the product of the stated interest rate and the combined account balances each year; and (as already noted) it is accrual rather than withdrawal that actually triggers taxation of the holder. In terms of cash flow, the amount initially deposited to the accounts is $\$ 10,000$, their collective balance after seven years (then found entirely in Account 2) is still $\$ 10,000$, and the holder has received $\$ 1,000$ (entirely from Account 3) in each intervening year. In financial terms, Account 2 is analogous to the bond without the coupons, while Account 3 is equivalent to the coupons separated from the bond. ${ }^{18}$ Put another way, Account 2 represents the

16 The point of this section is well documented in the literature. Those with a solid grounding in (or a distinterest in learning any more than they already know about) the original issue discount and coupon stripping rules may without loss of continuity proceed directly to Part III(B). The seminal article in the area is Canellos \& Kleinbard, The Miracle of Compound Interest: Interest Deferral and Discount After 1982, 38 Tax L. Rev. 565 (1983). A brief summary of the legislative history may be found in Sims, supra note 2, at 319-326. See also, e.g, Garlock, Federal Income Taxation of Debt Instruments Chs. 2, 5, 18 (2009). More generally see Halperin, Interest in Disguise: Taxing the "Time Value of Money", 95 Yale L.J. 506 (1986).

17 For two accounts with identical terms and interest rates, the observed relationship between the changes in value of the accounts holds if the periodic withdrawal from Account 3 equals the product of the stated interest rate and the combined initial balance in both accounts. (See Appendix, Part A-I.) The relationship would be preserved between payment dates, as the bond (and/or coupons) would change hands for its face amount plus interest accrued to the date of transfer. E.g., $S A B$ at 351.

18 See, e.g., BMA at 58-59. 
cash flow from an investment of $\$ 5,131.28$, that returns $\$ 10,000$ at the end of 7 years, while Account 3 represents the cash flows from an investment of $\$ 4,868.42$ that returns $\$ 1,000$ at the end of each of years 1 through 7 .

As such, these two accounts shed light on the conventional account of the taxation of the bond. The lesson of the comparison, by now fairly widely understood, is that treating a cashmethod holder of the bond as taxed on the coupon "interest" that she "receives" obscures what from a financial perspective is actually going on. In comparison, the holder of Account 2 is taxed without any receipt, while the holder of Account 3 is taxed on less than what she does receive. The coupon payments are simply a proxy, for taxing the accrual of value to the constituent payment obligations that make up the bond as a whole. ${ }^{19}$ Accounts 2 and 3 notionally decompose those obligations into two pieces, the "coupons" (3), and the underlying bond (2). But even that simple decomposition lays bare that what is being included in income is the accrual of value (using compound interest) to Accounts 2 and 3, not the $\$ 1,000$ periodic withdrawal from Account 3.

A complete decomposition would be into the eight, separate payment obligations, consisting of seven $\$ 1,000$ payments, each due at the end of one of seven consecutive years, and an additional \$10,000 also payable at the end of the seventh, that collectively constitute "the Bond." But to value those obligations individually we need to turn to "discounting," which to this point we have not explicitly introduced. Intuitively, discounting -- the computation of "present value" -- is just the inverse of compounding: if, as with Account 2, $\$ 5,131.58$ grows to $\$ 10,000$ in seven years with annual compounding at 10 percent, it follows that if 10 percent is the appropriate interest rate, the amount needed today to compound to $\$ 10,000$ in seven years would be $\$ 5,131.58$, and that is the "present" (or "discounted") value (at 10 percent) of $\$ 10,000$ to be received in seven years. Mathematically, if the "future value function" (1a) expresses future value $\left(\mathrm{V}_{k}\right)$ in terms of compound interest added at rate $r$ to some initial value $\mathrm{V}_{0}$, then the "present value" of $\mathrm{V}_{k}$ to be received $k$ periods from now is just that initial value, obtained generally by dividing both sides of (1a) by $(1+r)^{\mathrm{k}}$ to get the "present value function": ${ }^{20}$

19 The proxy is strictly accurate only for an instrument with a market coupon yield selling at par. See infra notes 25 and 31. A similar decomposition has been used to advantage by Chirelstein in explaining the treatment of gifts of income interests in trust that emerges from Irwin v. Gavit, 268 U.S. 161 (1925). Chirelstein, supra note 4, 4.02.

20 E.g., BMC at 114-15. The basic discrete-time and continuous discounting functions can be found in any MBAlevel finance text and are built into any standard spreadsheet. They are derived and illustrated, with a guide to their implementation in a spreadsheet, in Sims, Introduction to Discounting: Discrete Time (2009). 


$$
V_{0}=\frac{V_{k}}{(1+r)^{k}}
$$

(Since Account 2 assumes $r=0.10$ and $\mathrm{k}=7,(1+\mathrm{r})^{\mathrm{k}}=1.1^{7}=1.9487$; and the present value of $\$ 10,000$ discounted at 10 percent for seven years is $\$ 10,000 / 1.9487=\$ 5,131.58$.)

If, then, we divide our $\$ 10,000$ investment among eight different accounts, each paying ten percent, compounded annually, each funded with the present value (discounted at ten percent) of one of the eight payment obligations that collectively constitute the Bond, the amounts accrued as interest on the combined remaining balances in the (initially) eight accounts would again add up in every year to the amount paid as interest on the bond, in this instance $\$ 1,000$; and the serial liquidation of the eight accounts would produce a $\$ 1,000$ payment in each of the seven years, and $\$ 10,000$ more at the end. That is illustrated in Table 2. It reports the initial balance in seven accounts, used to fund the seven successive withdrawals, each obtained by dividing $\$ 1,000$ by the discount factor $\left(1.1^{\mathrm{k}}\right)$ appropriate to the number of years $(k=1,2, \ldots, 7)$ until it is to be paid (reported in brackets just above the initial balance in the account). Table 2 then reports the amounts accrued as interest in each period on each account until its balance reaches $\$ 1,000$, at which point that balance is withdrawn. Those amounts, when summed across all (remaining) accounts for each of the seven years, exactly replicate Account 3 (Table 1C); and when combined with the interest added each year to Account 2, again produce accruals that replicate the sequence of periodic payments on the Bond.

The phenomenon just described is reflected in the "coupon stripping" rules found in $\S$ $1286 .{ }^{21}$ If, immediately after issue, our bond were to be separated ("stripped") into its eight constituent pieces, that section would require each piece to be treated for income tax purposes essentially as illustrated in Table 2. Each would be valued at its present value (assuming at least annual compounding); and, since those present values would in all cases be less than the amount

21 An account of the origin and functioning of these rules may be found in Canellos \& Kleinbard, supra note 16 at 572-76; see also Sims, supra note 2, at 323-24 \& n. 46; Garlock, supra note 16 Chapter 18. The basic problem was that the conventional understanding of the bond, which treated the coupons as all "interest" and allocated basis in both the bond and coupons entirely to the underlying bond, led to transactions in which the coupons were stripped from the bond after issue with the bond then sold at an immediate loss. Such arrangements, at least those involving debt, have essentially been quelled by $\S 1286$, and by the added developments that (1) the Treasury ceased issuing debt in bearer form in 1982, and (2) that $\S 163$ (f) now denies any interest deduction to private issuers of debt in unregistered (i.e., bearer) form. 
eventually to be paid, each would be subject to the "original issue discount" (or "OID") rules of $\S \S 1272$ (a) and 1273(a). ${ }^{22}$ Stripped (sorry) to essentials, those rules require the holder of a debt instrument issued at a discount to include in income each year an amount equal to the product of its implicit yield at the time of issue (its "yield-to-maturity") ${ }^{23}$ and its value as of the beginning of that year. ${ }^{24}$ In effect, just as with Account 2, and with the seven separate accounts into which Account 3 is decomposed in Table 2, the holder of any stripped bond or coupon is taxed each year on $\mathrm{r}^{*} \mathrm{~V}_{k}$, just as given by (1). Viewed in that fashion, what Table 2 ultimately says is that the "interest" conventionally represented by the coupon payments on the Bond is at bottom a proxy for the amounts accrued as interest each year on all still outstanding constituent pieces of the bond. Just as with Accounts 2 and 3 themselves, the holder of the original Bond, while usually viewed as taxed on the "interest" she "receives," is effectively taxed using accrual. Section 1272(a) makes that explicit with respect to original issue discount debt; the implicit lesson of $\S 1286$ is that it is true of debt instruments generally. ${ }^{25}$

\footnotetext{
22 I.R.C. $\S \S 1286,1272(a), 1273(a)$.

23 "Yield-to-maturity" of a debt instrument is defined as that interest rate, which if used to discount all payments pursuant to the instrument to present value, produces discounted values that in the aggregate equal the instrument's "issue price." E.g., SAB at 112-14; BMA at 629-631; Income Tax Regulations § 1,1272-1(b)(1)(i).

24 I.R.C. § 1272(a)(3); Income Tax Regulations § 1.1272-1(b)(1). The statute is more complex, but the account in the text will suffice for present purposes. In statutory terms the holder is taxed on her periodic share (allocated within each period on a ratable daily basis) of the product of the instrument's yield-to-maturity and its "adjusted issue price" (basically its issue price adjusted upwards for amounts previously including in income). This taxes the holder on $r^{*} V_{\mathrm{k}}$ as given by (1). As described in the Appendix (A-I), for a pure discount bond, the statutory formula accurately reflects the pattern in which value accrues to the bond (or, indeed, to the present value of any future cash flow). For a more detailed description see, e.g., Garlock, supra note 16, Chs. $2 \& 5$.

25 I.R.C. $§ 1272$ (a), in other words, effectively puts all holders of debt on accrual accounting for OID, even if they are otherwise on the cash method. Section 1286 underscores that the holder of coupon bearing debt may also be viewed as implicitly taxed on accrual. There are, however, important exceptions to these rules, principally for debt that comes to trade at a discount or premium after issue, in which case the statute provides for taxation of market discount (or the deduction of bond premium) as ordinary income or loss on sale or surrender. See I.R.C. $\S \S 1276-78,171$. Both regimes provide, however, for elective accrual of the discount (as income) or premium (as a deduction) on an economic basis consistent with § 1272(a). I.R.C. $\S$ 1276(b)(2), 1278(b); Income Tax Regs. § 1.171-2(a). See infra note 31.

Given the centrality of accrual to the taxation of interest, even to cash-method holders of debt, it is hard to regard as sensible decisions holding that cash-method borrowers who satisfy their interest obligations by additional borrowing from their lenders are not allowed to deduct the interest because it hasn't been "paid." E.g., Battlestein v. Comm'r, 631 F.2d 1182 (5th Cir. 1980) (disallowing deduction where interest paid with borrowing from the same lender); compare Franklin v. Comm'r, 683 F.2d 125 (5th Cir. 1982) (allowing deduction where interest paid by borrowing from a different lender). The I.R.S. has ruled, in the case of margin interest charged to a cash method taxpayer via a brokerage account, that the interest is deductible to the extent paid out of prior receipts by the account of dividends or interest or proceeds from the sale of securities. Rev. Rul. 70-221, 1970-1 C.B. 33. In light of I.R.C. § 1272(a), such distinctions seem anachronistically formal.
} 
(B) "Depreciation" of Account 3. It isn't conventional to conceive of a bank account as "depreciable." But given the scheduled periodic withdrawals from Account 3 it is certainly possible to think about it that way. ${ }^{26}$ Each withdrawal produces a decline in the "value of" -- the balance remaining in -- the account. By how much does the balance decline? Not by the nominal withdrawal, because before that occurs at the end of each year, interest has been credited to the account. If, using (1), the interest credited during year $(k+1)$ is $\mathrm{r}^{*} V_{k}$, and the cash withdrawal at the end of that year is denoted $C_{k+1}$, the balance at the start of the following year, taking into account both, will be:

$$
V_{k+1}=V_{k}+r V_{k}-C_{k+1},
$$

from which it follows that

$$
V_{k}-V_{k+1}=C_{k+1}-r V_{k} \equiv D_{k+1}
$$

That is, the decline in value $\left(D_{k+1}\right)$ from year $k$ to $k+1$ is the nominal withdrawal at the end of the year, reduced by the interest accrued during the year, and $D_{k+1}$ may at least be thought of as the amount by which the account "depreciated" in year $k+1$, expressed as a positive number. (Those changes are reported as negative numbers in the final column of Table 1, Panel C.) What is more, if viewed as "depreciation," the changes reflect the actual decline in the account balance (value) each year, so that they amount to "economic" depreciation. ${ }^{27}$

This may seem a needlessly elaborate way of describing an intuitively simple phenomenon. We know that a bank account grows because interest is credited and decreases because of withdrawals, and that the change in the balance from one year to the next is just the sum of those events. That is all that $D_{k+1}$ says. Worse, it seems circular to add, because it is true simply by rearrangement of (2), that if a withdrawal $\left(C_{k+1}\right)$ is treated as "cash flow" generated by the account, from which our measure of "depreciation" $\left(D_{k+1}\right)$ is subtracted for purposes of determining the amount to be taxed, we just get back

\footnotetext{
26 As a financial asset, "amortization," typically used to describe the periodic retirement of a loan, is conventionally the more appropriate term, but for expositional consistency I use "depreciation" pretty much throughout.

27 See supra text at note 1. The generally increasing pattern of depreciation exemplified in Table 1C -- here increasing from \$513 in year 1 to \$909 in year 7 -- so-called "sinking-fund" depreciation, is appropriate for an asset with constant, finite productivity (often called, after Holmes' "The Deacon's Masterpiece," a "one-hoss shay" -- that is, a carriage -- "That was built in such a logical way/It ran a hundred years to a day," after which "it went to pieces all at once, ... and nothing first,--/Just as bubbles do when they burst.") An account (of the depreciation) may be found in Chirelstein, supra note 4, § 6.09; see also Hulten \& Wykoff, supra note 3, at 88-90.
} 


$$
C_{k+1}-\left(C_{k+1}-r * V_{k}\right)=r * V_{k},
$$

when we knew all along that what is taxed to the holder of a bank account is the interest credited to the balance in the account. Having thus demeaned the observation as true by construction, let me nevertheless underscore that treating each withdrawal as includible in income and subtracting $D_{k+1}$ as (economic) depreciation does reproduce the amount that we know to be properly includible in income. That is, treating each year's $\$ 1,000$ "cash flow" as includible in income and subtracting our measure of "economic depreciation" produces $\$ 487$ in year $1, \$ 436$ in year 2 , and so on, and these amounts in each case equal $r^{*} V_{k}$. So if we are right in viewing Expression (2) as somehow characterizing economic depreciation, it follows that, in the context of Account 3 at least, economic depreciation and accrual taxation are equivalent.

\section{Economic Depreciation More Generally}

We are generally accustomed to thinking of depreciation as reflecting the decline in value of physical capital owing to wear, tear, and obsolescence, or to the decay in the value of intangible assets due to technological change or the myriad other effects of the passage of time. In practice, efforts to determine depreciation rates empirically center on estimating how the market prices of productive assets evolve over time. Against that background, the account of "economic depreciation" at the end of Part III may seem farfetched. It is nevertheless, at least at a conceptual level, central to the notion of economic depreciation.

To see this, consider Asset 4, depicted in Table 3, consisting of an uneven, more or less arbitrarily selected sequence of five cash flows. In this example it is assumed that the cash flows represent operating income net of expenses other than taxes and depreciation. ${ }^{28}$ In panel A the cash flows have been arrayed horizontally in Row 0. At the assumed purchase price of just under $\$ 5,700$ this asset has an "internal rate of return" of 10 percent, ${ }^{29}$ the same as the rate at which

28 In accordance with experience the net operating income from the asset (before interest, taxes, depreciation and amortization) has been modelled as decaying over time. E.g., Hulten \& Wykoff, supra note 3, at 84-86; Hulten, Getting Economic Depreciation Almost Right (2008) (available at http://econweb.umd.edu/ hulten/WebPageFiles/Getting\%20Economic\%20Depreciation\%20Almost\%20Right.pdf).

29 An investment's "internal rate of return" is defined as that interest rate which, if used to discount each of the net cash flows from the investment, produces discounted values that in the aggregate equal its purchase price. E.g., $S A B$ at 524-26; BMA at 91-99. As such it is formally identical to the "yield-to-maturity" on a debt instrument. See supra note 23. If the internal rate of return equals the discount rate for the investor, which we here assume to be the case, the investment has a zero "net present value". Ibid. Just what the appropriate discount rate is for a given investor is studied extensively in corporate finance. E.g., BMA at Chs. 9 and 17. 
interest is credited in our previous examples. Discounted at that rate to the date of acquisition, the present values of the cash flows from the asset add up to its purchase price $(\$ 5,700)$, as illustrated in Row 1 and summarized in Column (6) of Table 3.

To determine "economic depreciation" from this asset we need to ascertain the present values, at the beginning of each of the remaining four years of the asset's life, of all then remaining cash flows. Economic depreciation is just the year-to-year change in those present values. So, for example, at the start of year 2, when only four cash flows remain, their aggregate present value, discounted to the beginning of year 2, is $\$ 3,269.24$, as reported in Row 2 (and again summarized in Column (6)). Hence, as reported in Column (7) in Panel B, the asset depreciates during year 1 from $\$ 5,699.31$ to $\$ 3,269.24$, or by $\$ 2,430.07$. The remaining four depreciation allowances, determined in the same way, are collected in Column (7), and the sequence of cash flows is reiterated vertically in Column (8). Treating the holder as taxable on the net cash flow, after subtracting the allowance for economic depreciation as we have computed it, produces taxable income reported in Column (9).

Observe, in contrast with Account 3, that we have not directly imputed any yield to Asset 4. ${ }^{30}$ We have instead taxed the holder on operating cash flow minus the actual annual change in its value. Nevertheless, taxable income in each period, expressed as a percentage of the asset's value at the beginning of that period and reported in Column (10), turns out to be 10 percent, exactly equal to its pre-tax internal rate of return. As we have computed it, however, Asset 4's value at the beginning of each period -- or, equivalently, at the end of each preceding period -- is just the sum of the present values of its remaining cash flows. As such those values are analogous to the balances in Account 3 at the end of each year. So we are justified in also denoting those values, as of the end of any period $k$, by $V_{k}$. With that notation what is taxed in each succeeding period $(k+1)$ is just $r^{*} V_{k}$, where $r$ is now the pre-tax internal rate of return. Here, then, an allowance for what we have directly calculated to be economic depreciation again induces accrual taxation.

Expressed algebraically, what Table 3 implies is that cash-flow in any period $(k+1)$, minus calculated economic depreciation during period $k+1$, produces taxable income of $r^{*} V_{k}$ :

30 That is, we have allowed the collection of cash flows to determine for us the internal rate of return; used that to find each year-to-year change in the present value of the remaining cash flows; and then taxed the holder on each cash flow minus the resulting schedule of depreciation. 


$$
C_{k+1}-D_{k+1}=r * V_{k},
$$

from which by rearrangement it again follows that "economic depreciation" is given by

$$
D_{k+1}=C_{k+1}-r * V_{k} \text {. }
$$

So the natural inference to be drawn from Asset 4 is that economic depreciation is given by the same expression derived intuitively (but circularly) from consideration of Account 3. It suggests, more persuasively than might have been inferred from our treatment of Account 3 alone, that "economic depreciation" is more generally captured by Expression (2).

Stated differently, with Account 3 we calculated the change in the account balance $\left(V_{\mathrm{k}}\right)$, assuming that interest was credited directly to that balance, by adding the interest and subtracting each payment, to get $V_{\mathrm{k}+1}$. With Asset 4, in contrast, we started with the bare sequence of cash flows -- it could have been pretty much any sequence of cash flows -- determined the internal rate of return, and used that to determine the economic depreciation schedule implied by those values. We then determined taxable income, defined as cash flow minus economic depreciation, to find that what was taxed in each period was the product of the internal rate of return and the asset's value at the beginning of that period. Two differing approaches -- one beginning with the direct accrual of interest, the other with the determination of economic depreciation for a prescribed set of cash flows -- have thus led us to equivalent outcomes in terms of what is to be included in income. They are flip sides of the same coin. ${ }^{31}$

31 Under existing law, at least insofar as the tax treatment of debt is concerned, they actually exist on something approaching a continuum, taking into account the statutory treatment of OID, on the one hand, and (elective) treatment of "bond premium" under I.R.C. § 171 and Income Tax Regs. $\$ 1.171-2(\mathrm{a})(3)(\mathrm{iii})$, on the other. As to the latter, the regulation allows the holder of a bond acquired for more than the amount payable at maturity, and so having a true yield that is less than its coupon (or stated) interest rate, to deduct against the stated interest on the bond in each period the excess of the stated interest over the product of the bond's yield and the holder's "adjusted acquisition price." In other words, the allowable deduction is $C_{k+1}-r^{*} V_{k}$, where $C_{k+1}$ is the payment of stated interest, and $V_{k}$ is the holder's adjusted acquisition price. Thus, the regulatory formulation is just economic "depreciation", as given by (2), and since the stated interest $\left(C_{k+1}\right)$ is includible in income under I.R.C. $\S 61(\mathrm{a})(4)$, this combination of provisions taxes the holder on $C_{k+1}$ $\left(C_{k+1}-r^{*} V_{k}\right)=r^{*} V_{k}$. As a formal matter the treatment of OID is slightly different, in that it adds includible OID to the stated interest includible under $\S$ 61(a)(4). But includible OID in each period is defined as the excess of the product of the bond's yield and the holder's "adjusted issue price" over the bond's stated interest, or $r^{*} V_{k}-C_{k+1}$, where $V_{k}$ is now the statutory adjusted issue price. But adding OID, as so defined, is algebraically the same as subtracting $C_{k+1}{ }^{-}$ $r^{*} V_{k}$, so that the two formulations are equivalent. In effect, Expression (2) defines economic depreciation if $C_{k+1}>r^{*} V_{k}$ (cash flow exceeds yield, as with bond premium), and (economic) appreciation if $C_{k+1}<r^{*} V_{k}$ (as it does with OID). Compare Fisher, The Nature of Capital and Income. supra note 6, at 237-38. 
The question that remains is just how general the result actually is. The answer given in the Appendix (Part A-II, and the companion piece on which it draws) is that, for an arbitrary sequence of cash flows $\left\{C_{1}, \ldots, C_{\mathrm{N}}\right\}$, with discounted value $\mathrm{V}_{k}($ for $k=0,1,2, \ldots, N-1)$, the value of the cash flows remaining at the end of period $k+1$ is given by

$$
V_{k+1}=(1+r) V_{k}-C_{k+1},
$$

from which it follows that the change in value from period $k$ to $k+1$ is

$$
V_{k}-V_{k+1}=C_{k+1}-r V_{k}
$$

or $\mathrm{D}_{\mathrm{k}+1}$, as already given by Expression (2).

At this point it seems in order to return to the search for a one-line answer to the question posed at the end of the Introduction. From a conceptual perspective, $\mathrm{D}_{k+1}$, as defined by Expression (2), is economic depreciation. ${ }^{32}$ It consists of (1) the cash flow realized in period $k+1$, minus (2) the product of the asset's internal rate of return and its value at the beginning of that period. So when, as in (3), the holder of the asset is taxed in each period on cash flow minus economic depreciation, as given by (2), the effect is always to tax her on $r^{*} V_{k}$, just as given by (1).

The intuition for this turns out to be relatively simple. When an asset is periodically valued as the sum of its discounted cash flows, two things occur between the beginning and the end of each period. One is that each constituent cash flow comes one period closer to realization, is therefore discounted for one fewer periods, and so increases in value by the product of its value at the beginning of that period and the rate used in discounting it to present value ${ }^{33}$ since the value of the asset as a whole is just the sum of the present values of its constituent cash flows, that value undergoes the same change. The other is that the current period's cash flow is realized. The question is how those two phenomena should be taken into account for purposes of taxation. In

32 Note that it conforms in principle to the empirical definition of economic depreciation as the period-to-period change in the market value -- the so-called "age-price profile" -- of a depreciable asset. E.g., Hulten \& Wykoff, supra note 3, at 84-90. As Asset 4 has been modelled the depreciation schedule by definition traces out the changes in its value over time. What is more, the adjusted basis of the asset at the end of each period would equal the remaining present value used in constructing the depreciation schedule.

33 That is, just as with a pure discount bond, the change in present value of any future cash flow, as it comes one period closer to receipt, is just $r^{*} V_{\mathrm{k}}$, where $V_{\mathrm{k}}$ is now that cash-flow's value at the beginning of the period. See the discussion above at note 24 . 
answering that question it is essential to recognize that, in a world in which assets are valued as the sum of their discounted cash flows and holders are to be taxed on changes in net worth, the reduction to possession of an expected cash flow from an asset has no impact on the holder's financial well being. At the moment of realization the positive impact of any cash flow is offset by a corresponding reduction in the value of the asset from which it was derived; together, the two induce no change in the holder's net worth. ${ }^{34}$ And so, to the extent that changes in net worth are viewed as a touchstone for taxation, the mere realization of an expected receipt should not properly occasion the imposition of tax. That is what accounts for the term $\mathrm{C}_{k+1}$ in Expression (2). It reflects the decline in the asset's value attributable to the disappearance of that cash flow, and offsets that decline against the realized cash flow itself. What remains, $r^{*} V_{k}$, reflects that with the passage of time the value of the entire set of cash flows has increased by the rate of return on the asset; only that increase remains to be included in income. It is in that sense that economic depreciation implements pure accrual taxation.

V. The Samuelson Theorem

This endeavor set out to explore the relationships among economic depreciation, accrual taxation, and the Samuelson theorem. Given the essential duality of the first two, it can be maintained that the mechanism underlying Samuelson's conclusion, developed in discrete time here, provides a conceptual foundation for the study of accrual taxation of capital income generally. Before getting there, however, ${ }^{35}$ it seems right to conclude the analysis by illustrating the operation of the Samuelson theorem itself. In so doing we restrict ourselves to observing that Expression (2) is sufficiently general to describe Account 2, as well as Account 3 and Asset 4; and, on that premise, to use Account 2 to illustrate the theorem's operation in the simplest of settings.

\footnotetext{
34 Immediately before realization the current period cash flow is no longer discounted, so that its value in cash immediately after realization is identical to its value as part of the asset the moment before. This observation has the same flavor as the textbook observation (so hard for students initially to grasp) that the effect of Eisner v. Macomber, 252 U.S. 189 (1920), was to tax precisely that set of events -- exchanges of appreciated assets for cash (or some other asset) of equal value -- that do not affect the holder's financial well-being. Thus, it is to be expected that on the date as of which a cash distribution by a corporation becomes payable (the "ex-dividend" date) the share price should (everything else being equal) decline by an offsetting amount. Although the noise inherent in public securities markets may pose challenges in detecting such effects, Microsoft has obliged us with one spectacular example, in the form of a \$3.08/share cash distribution (equal to about 10 percent of its then prevailing market value) at the end of 2004 . See Chetty, Rosenberg, and Saez, The Effects of Taxes on Market Responses to Dividend Announcements and Payments: What Can We Learn From the 2003 Dividend Tax Cut, in Auerbach, Hines \& Slemrod, Taxing Corporate Income in the 21st Century, at 1-6 (2007). The close-to-open fall in Microsoft's share price on the ex-dividend date (November $12,2004)$ was $\$ 2.63$.

35 See infra Part VI.
} 
As to the first point it is sufficient to note that by setting $C_{k+1}=0$ in all but the final period -- there are no withdrawals until "the end"36 -- Expression (2) says that "depreciation" in each other period is

$$
-r * V_{k}
$$

that is, depreciation is negative, and when subtracted from the cash flow -- $\$ 0.00$-- yields taxable income of $r^{*} V_{k}$. So to think of it this way does reproduce the intuitively sensible result for Account 2, as well as Account 3. ${ }^{37}$ The payoff is that, at least conceptually, we may think of interest accruing in a bank account as taxable income, defined now as cash flow (\$0) minus economic depreciation as defined by Expression (2), in which case it satisfies the conditions of the Samuelson theorem. ${ }^{38}$

With that understanding, the Samuelson theorem leads us to expect that the value of Account 2 should be independent of the holder's tax rate, a result that is illustrated in Table 4. Start with Panels A and B of Table 4-1, which depict the phenomenon in two different ways. The first, and more accessible, assumes that taxes are paid out of the account, illustrated using a tax rate of 40 percent in Table 4-1A. The accrual of value is much like that in Table 1B, except that the account balance is reduced by taxes, with the result that the balance is lower each year in Table 4-1A. In seven years the balance compounds to $\$ 7,716$, at an after-tax interest rate of 6 , rather than 10 percent, reflecting the reduction in each year's accrued interest by the product of the 10 percent interest rate and the 40 percent tax rate. But since in that environment the discount rate that would be used by a 40 percent bracket taxpayer is likewise 6 percent, it follows immediately that the present value of the $\$ 7,716$ final balance is just $\$ 5,131.58$, because, with the reduction of both the growth rate and the discount rate by taxes to 6 percent, the impact of taxes on the account growth and discounting exactly offset one another. ${ }^{39}$ The example thus suggests, on a discounted

\footnotetext{
36 As would be the case with a pure original issue discount bond, or, on the expense side, with an investment requiring an outlay at the very end of its life, of the sort studied (for example) in Kiefer, The Tax Treatment of a Reverse Investment, 26 Tax Notes 925 (1985).

37 Samuelson himself observed generally that, since the form of the depreciation allowance is "algebraic", when negative it captures appreciation in the value of an asset. See supra note 4 . In the terms described in note 31, supra, this is just the case $C_{k+1}<r^{*} V_{\mathrm{k}}$ because each interim cash flows is 0 . The final period cash flow is $C_{\mathrm{N}}>0$, while depreciation is $D_{\mathrm{N}}=C_{\mathrm{N}}-r^{*} V_{\mathrm{N}-1}$, so cash flow minus depreciation is again just $=r^{*} V_{\mathrm{N}-1}$.

38 See Kiefer, The Tax Treatment of a Reverse Investment, 26 Tax Notes 925, 926 (1985).

39 See supra note $7,3$.
} 
basis, that the account has exactly the same value after taxes as before. What is more it has that property regardless of the period from which its balance is discounted, as reflected in column (4) of Table 4-1A.

That might (or may not) be striking, but almost surely it is at least as unsatisfying, in that at bottom it seems to say little more than that the amount initially deposited to a bank account is worth whatever was deposited in the account. Bank accounts are not known to fluctuate in (nominal) value, and we reflexively take money in the bank to have the same value to all. So what is illustrated in Table 4-1A seems too trivial to be persuasive. ${ }^{40}$ The same, however, cannot be said of a debt instrument analog to Account 2, namely a non-interest bearing pure discount bond purchased for $\$ 5,131.58$ and redeemable for $\$ 10,000$ in seven years. Although, as noted above, $\S$ 1272(a) now taxes such instruments like money in a bank, in the absence of current payments the taxes cannot be satisfied from the bond itself, and so must be paid from other sources. Consequently, discount on the instrument accrues as it would in the absence of tax. What is more, in contrast with an account with a bank, the debt instrument is free to fluctuate in response to taxation, as well as to other determinants of value.

That version is reported in Table 4-1B. As would be the case if an instrument with these characteristics were actually issued, the discount accrues in the same pattern as it would in Account 2 in the absence of taxation, exactly as reflected in Table 4-1B. And the taxes attracted by the accruing discount, which by hypothesis exceeds the interest credited to and taxed in the bank account in 4-1A, must be paid with other funds. We would nevertheless intuitively expect, at least as long as the opportunity cost of financing those payments was the same as the opportunity cost (10 percent, pre-tax) of the amounts withdrawn from Account 2 to pay the taxes in Table 4-1A, that the overall after-tax consequences would be the same. ${ }^{41}$ That they are is confirmed by Table 4-1B, the first three columns of which report the adjusted issue price, the accrual of discount, and the taxes paid (at 40 percent, reported as negative numbers) in respect of the instrument each year. Column (4) discounts each tax payment to present value on the date of

40 It should be noted, however, that if for some reason the law were to prescribe a rate at which interest accrued for tax purposes on bank instruments that was faster (and hence more disadvantageous) than economic accrual, such instruments would cease to have the same value to everyone. That is essentially what happened with respect to original discount debt between 1969 and 1981, when the law prescribed ratable accrual of OID and, the demand for pure discount bonds simply dried up. See, e.g., Sims, Long Term Debt, The Term Structure of Interest and the Case for Accrual Taxation, 47 Tax L. Rev. 313, 320-322 (1992).

41 Klein, Borrowing to Finance Tax-Favored Investments, 1962 Wis. L. Rev. 608. 
issue, using an after-tax discount rate of 6 percent, over the number of periods until it is made, while Column (5) discounts (at 6 percent) the adjusted issue price at the end of each period for that number of periods.

What is then reported in Column (6), for each year the instrument is outstanding, is the sum of (a) the present value of the adjusted issue price in that year, plus (b) the aggregate present value of all taxes paid through the end of that year. Thus, Column (6) reports the sum of the present values of all cash flows from the instrument through the end of each year, in effect the present value of the cash flows that would be derived from the bond assuming it could have been (and were to be) sold or surrendered in that year. They again add up to $\$ 5,131.58$, and they do so in every period. Either way, then, much as we would expect, the two versions yield the same outcome, namely that from whatever period the after-tax cash flows are discounted, they always add up to $\$ 5,131.58$, equal to the nominal price of the bond.

This is not just an artifact of the numbers involved. It is, in particular, independent of the tax rate, as illustrated in Panels A and B of Table 4-2, which report the same calculations using a 25 percent rate. Once again the value is always $\$ 5,131.58$, discounted (now at 7.5 percent) from any period. (Part III of the Appendix shows that this is generally the case.) So for either Account 2 , or its OID counterpart, when the holder is taxed on accrual, value is independent of the tax rate, just as the Samuelson theorem predicts.

\section{Some Concluding Observations}

The U.S. income tax remains quite a distance from implementing "economic" depreciation. It nevertheless remains an important conceptual benchmark in the analysis of capital income taxation. As established by the Samuelson theorem (and illustrated in Part V), economic depreciation leads to a system with the attractive property of "neutrality," in the sense that the values of productive assets do not differ across taxpayers depending on their marginal rates. And as suggested in the introduction, the insight, formalized in Parts III(B) and IV, that economic depreciation and accrual taxation are equivalent and therefore share that property, will accord with the informed intuitions of many tax professionals. What the analysis here contributes, and a principal objective of the project, is a rigorous foundation for that intuition, using discrete rather than continuous mathematics.

As also noted in the introduction, however, the exact form of the depreciation allowance that produces this result, given by Expression (2), is itself of considerable interest. That latter 
seems to be less widely understood. And so a second objective of the paper has been to highlight the nature and significance of that allowance. For one thing, as already observed at the conclusion to Part IV, it underscores that, where assets are (as they generally should be) valued as the sum of their discounted cash flows, the actual realization of an anticipated cash flow from an asset has no effect on the holder's net worth. That is not just a characteristic of amounts technically "realized" under $\S 1001$, something that is a staple of classroom treatments of Eisner v. Macomb$e r{ }^{42}$ What Expression (2) captures is that it is characteristic of receipts from property generally. That insight carries the implication, likewise reflected in Expression (2), that if increases in financial well-being are to be the basis for taxation, "income" from property in the sense of what should ideally be reached by an accretion-style tax consists of accrued changes in value, not (as cash-flow taxation advocates would have it) ${ }^{43}$ of realized cash flow.

Just as importantly, the operational relevance of Samuelson's analysis is broader than is generally appreciated. His original paper was expressly about depreciation. As a formal matter, however, it is a solution to the more general question "To insure invariant valuation, what deduction(s) should be allowed in determining taxable income from an asset?" As such it addresses not merely the allowance of ongoing deductions for the recovery of asset costs -- "depreciation," as conventionally understood -- but income taxation of the entire range of asset-related costs. It speaks, in other words, not merely to depreciation, but to acquisition and retirement costs, that is, to such matters as "capitalization," and the recovery of what are usually called "future costs," and perhaps

42252 U.S. 189 (1920). See supra note 34.

43 Just what constitutes "income," and should properly be taxed, has been controversial at least since the work of Irving Fisher and Henry Simons. Fisher, Income in Theory and Income Taxation in Practice, 5 Econometrica 1 (1937); Simons, Personal Income Taxation 89-100, 225-231 (1938).

More recently, Jeff Strnad has argued that a cash-flow tax is superior to an accretion-style tax at reaching (and reducing by the marginal tax rate) changes in value as they accrue; in that sense, he claims, a cash-flow tax more faithfully implements the Haig-Simons goal of taxing changes in net worth. Strnad's argument seems to depend heavily on the methodological assumption that investments have ex ante positive "net present values," and his central premise is that such net present values must be reduced by the marginal tax rate in a system that faithfully implements what he interprets as the Haig-Simons ideal. What the analysis here suggests is that the Haig-Simons tax base may as plausibly be viewed as reducing returns to wealth as they accrue, while leaving asset values -- wealth, as conventionally understood -- unaffected. On that view of things, Samuelson's result implements Haig-Simons taxation, rather than being something distinct from it, as Strnad explicitly suggests. Strnad, Tax Timing and the Haig-Simons Ideal: A Rejoinder to Professor Popkin, 62 Ind.L. J. 73, 77 \& n. 16 (1986); see also Strnad, Taxation of Income From Capital: A Theoretical Reappraisal, 37 Stan. L. Rev. 1023 (1985); Kaplow \& Warren, An Income Tax by Any Other Name -- A Reply to Professor Strnad, 38 Stan. L. Rev. 399 (1986); Strnad, The Bankruptcy of Conventional Tax Wisdom Is Deeper Than Semantics: A Rejoinder to Professors Kaplow and Warren, 39 Stan. L. Rev. 389 (1987); Kaplow \& Warren, Professor Strnad's Rejoinder: Simply Semantics, 39 Stan. L. Rev. 419 (1987). Perhaps the most succinct, accessible account of Strnad's basic argument is that found in the Popkin rejoinder. 
even farther afield to other historically vexing issues like the taxation of advance receipts. ${ }^{44}$ While all such phenomena have always been understood to be intimately related, what I suggest here is the possibility that Expression (2) might in one place, in principle at least, guide the way to "neutral" tax treatment of all of them.

Each such topic deserves consideration on its own. Many already have received it. ${ }^{45}$ But it is easy to illustrate the basic insight using capitalization, elaborating on the account of Expression (2) articulated at the end of Part IV. Our basic intuition about capitalization is that an outlay to acquire something durable leaves the holder with value equal to the amount expended to acquire it. ${ }^{46}$ Capital outlays therefore do not alter the investor's net worth, and hence should not be allowed as a deduction. But that is exactly the treatment prescribed by Expression (2) at the outset of an asset's life. As of the moment before its acquisition by a taxpayer an asset, consisting of a sequence of cash flows $\left\{C_{1}, \ldots, C_{\mathrm{N}}\right\}$ has no value to her. And if she were to acquire it for an outlay $\left(C_{0}\right)$ equal to the present value of those cash flows, its net present value, taking into account both the initial outlay and the subsequent cash flows, would still be zero. ${ }^{47}$ Either way the value, in effect, is $V_{-1}=0$. The question, then, is how to account for the initial outlay

44 It has long been understood that the pivotal difference between an accrual- (or "accretion-") type income tax and a cash-flow tax is the treatment of asset costs and returns, with the latter characteristically allowing the costs of longlived assets to be deducted currently, and the former requiring some form of (ideally, "economic") depreciation. E.g., Brown, Business-Income Taxation and Investment Incentives, in Income, Employment and Public Policy: Essays in Honor of Alvin H. Hansen 309-310 (1948), reprinted in Readings in the Economics of Taxation (1959); Andrews, supra note 1, at 1126-28. One way of thinking about the relevance of Expression (2) for the design of an accretion style tax, however, is that it suggests that all property income should be taken into account on receipt, not using accrual, with proper measurement of net income then being achieved by the allowance of deductions in the manner implied by Expression (2). I am indebted to Daniel Halperin for suggesting this way of looking at the matter.

45 That the literature on capitalization is vast requires no citation. A series of articles in the 1980's addressed the matter of future costs, but without arriving at any consensus about whether some version of economic depreciation, as contemplated by Samuelson's work, or something equivalent to simple cash accounting, was correct. A survey, together with an extended consideration of the issue using Samuelson's original continuous time framework, can be found in Sims, Natural Capitalization, supra note 6. The earlier papers were provoked by legislative consideration of ways of accounting for income tax purposes of nuclear power plant decommissioning expenses and strip-mining reclamation costs, now dealt with by $\S \S 468$ and 468A. See, e.g., Noël B. Cunningham, A Theoretical Analysis of the Tax Treatment of Future Costs, 40 Tax Law Review 577 (1985); Daniel I. Halperin and William A. Klein, Tax Accounting for Future Obligations: Basic Principles Revised, 38 Tax Notes 831 (1988); Donald W. Kiefer, The Tax Treatment of a Reverse Investment, 26 Tax Notes 925 (1985); Emil M. Sunley, Observations on the Appropriate Tax Treatment of Future Costs", 24 Tax Notes 719 (1984).

46 It would be more natural to refer to the acquisition of an "asset" with durable value, but such language seems out of keeping with the ruling in Indopco v. Comm'r, 502 U.S. 79 (1992), which held that creation of a separate and distinct asset was not essential to capitalization. Compare Lincoln Savings \& Loan v. Comm'r, 403 U.S. 345 (1971).

47 See Fisher, Income in Theory and Income Taxation in Practice, supra note 6 at 6 \& n.9; see also Sims, Natural Capitalization, supra note 6 , at 710-711. 
$\left(C_{0}\right)$. Although $C_{0}$ is by assumption negative, its sign does not affect the treatment prescribed by Expression (2). That is still just the initial cash flow $\left(C_{0}\right)$, minus economic depreciation $\left(D_{0}\right)$, or

$$
\begin{gathered}
C_{0}-D_{0}=C_{0}-\left(C_{0}-r V_{-1}\right) \\
=r V_{-1}=0 .
\end{gathered}
$$

In other words, when deployed to analyze the tax treatment of the acquisition of an asset, Expression (2) prescribes no tax consequences -- no income, and no deduction -- consistent with both our intuitions and with the treatment actually given by the capitalization requirement of $\S 263$. Put differently, and for present purposes more to the point, it shows that the capitalization requirement is itself an integral element of Samuelson's invariance result.

This simple example suggests, then, though at this point it is only suggestive, that economic "depreciation" in the form of Expression (2), as highlighted in this paper, offers a new lens through which to view issues involving the taxation of capital income generally. To the extent that tax neutrality across assets continues to be viewed as in principle desirable, the exercise of applying that insight holds out the possibility of shedding fresh light on some of the historically more thorny technical details of property income taxation. 
Table 1.

\begin{tabular}{|c|c|c|c|c|c|c|c|c|c|c|c|c|c|}
\hline \multirow[b]{3}{*}{ Year } & & \multicolumn{3}{|c|}{ A. BOND } & \multicolumn{2}{|c|}{ B. AcCount 2} & \multicolumn{4}{|c|}{ C. Account 3} & \multicolumn{3}{|c|}{ D. ACCOUNTS $2 \& 3$} \\
\hline & & Balance & Interest & Payment & Balance & Interest & Balance & Interest & Payment & Change & Balance & Interest & Payment \\
\hline & Initial & 10000.00 & & & 5131.58 & & 4868.42 & & & & 10000.00 & & \\
\hline 1 & Interest & & 1000.00 & & & 513.16 & & 486.84 & & & & 1000.00 & \\
\hline & Payment & & & -1000.00 & & & & & -1000.00 & & & & -1000.00 \\
\hline & Balance & 10000.00 & & & 5644.74 & & 4355.26 & & & -513.16 & 10000.00 & & \\
\hline 2 & Interest & & 1000.00 & & & 564.47 & & 435.53 & & & & 1000.00 & \\
\hline & Payment & & & -1000.00 & & & & & -1000.00 & & & & -1000.00 \\
\hline & Balance & 10000.00 & & & 6209.21 & & 3790.79 & & & -564.47 & 10000.00 & & \\
\hline 3 & Interest & & 1000.00 & & & 620.92 & & 379.08 & & & & 1000.00 & \\
\hline & Payment & & & -1000.00 & & & & & -1000.00 & & & & -1000.00 \\
\hline & Balance & 10000.00 & & & 6830.13 & & 3169.87 & & & -620.92 & 10000.00 & & \\
\hline 4 & Interest & & 1000.00 & & & 683.01 & & 316.99 & & & & 1000.00 & \\
\hline & Payment & & & -1000.00 & & & & & -1000.00 & & & & -1000.00 \\
\hline & Balance & 10000.00 & & & 7513.15 & & 2486.85 & & & -683.01 & 10000.00 & & \\
\hline 5 & Interest & & 1000.00 & & & 751.31 & & 248.69 & & & & 1000.00 & \\
\hline & Payment & & & -1000.00 & & & & & -1000.00 & & & & -1000.00 \\
\hline & Balance & 10000.00 & & & 8264.46 & & 1735.54 & & & -751.31 & 10000.00 & & \\
\hline 6 & Interest & & 1000.00 & & & 826.45 & & 173.55 & & & & 1000.00 & \\
\hline & Payment & & & -1000.00 & & & & & -1000.00 & & & & -1000.00 \\
\hline & Balance & 10000.00 & & & 9090.91 & & 909.09 & & & -826.45 & 10000.00 & & \\
\hline 7 & Interest & & 1000.00 & & & 909.09 & & 90.91 & & & & 1000.00 & \\
\hline & Payment & & & -1000.00 & & & & & -1000.00 & & & & -1000.00 \\
\hline & Balance & 10000.00 & & & 10000.00 & & 0.00 & & & $\begin{array}{c}-909.09 \\
\cdots \cdots \cdots . . . . . .\end{array}$ & 10000.00 & & \\
\hline & TOTAL & & 7000.00 & -7000.00 & & 4868.42 & & 2131.58 & -7000.00 & & & 7000.00 & -7000.00 \\
\hline
\end{tabular}


TABLE 2

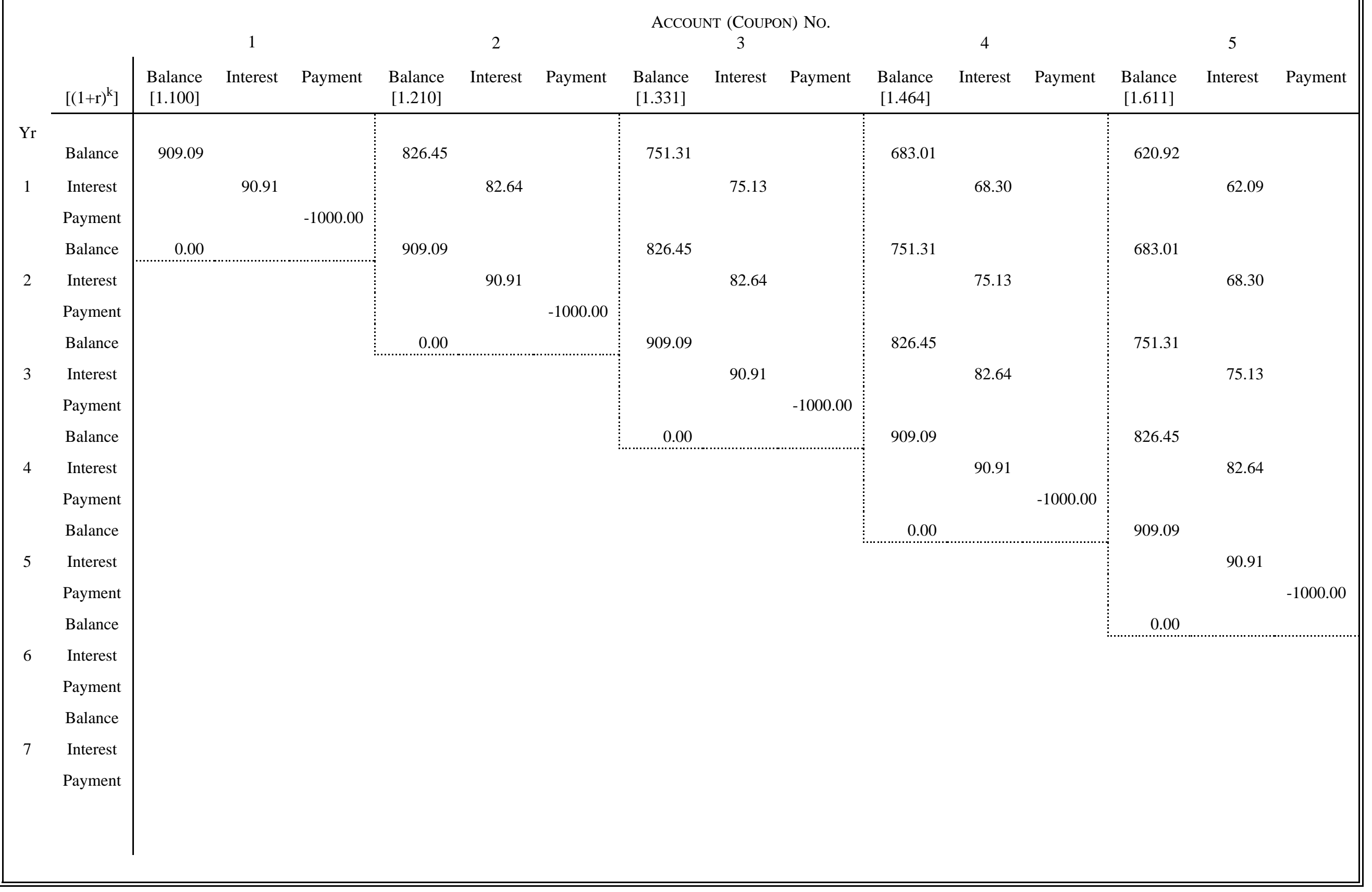




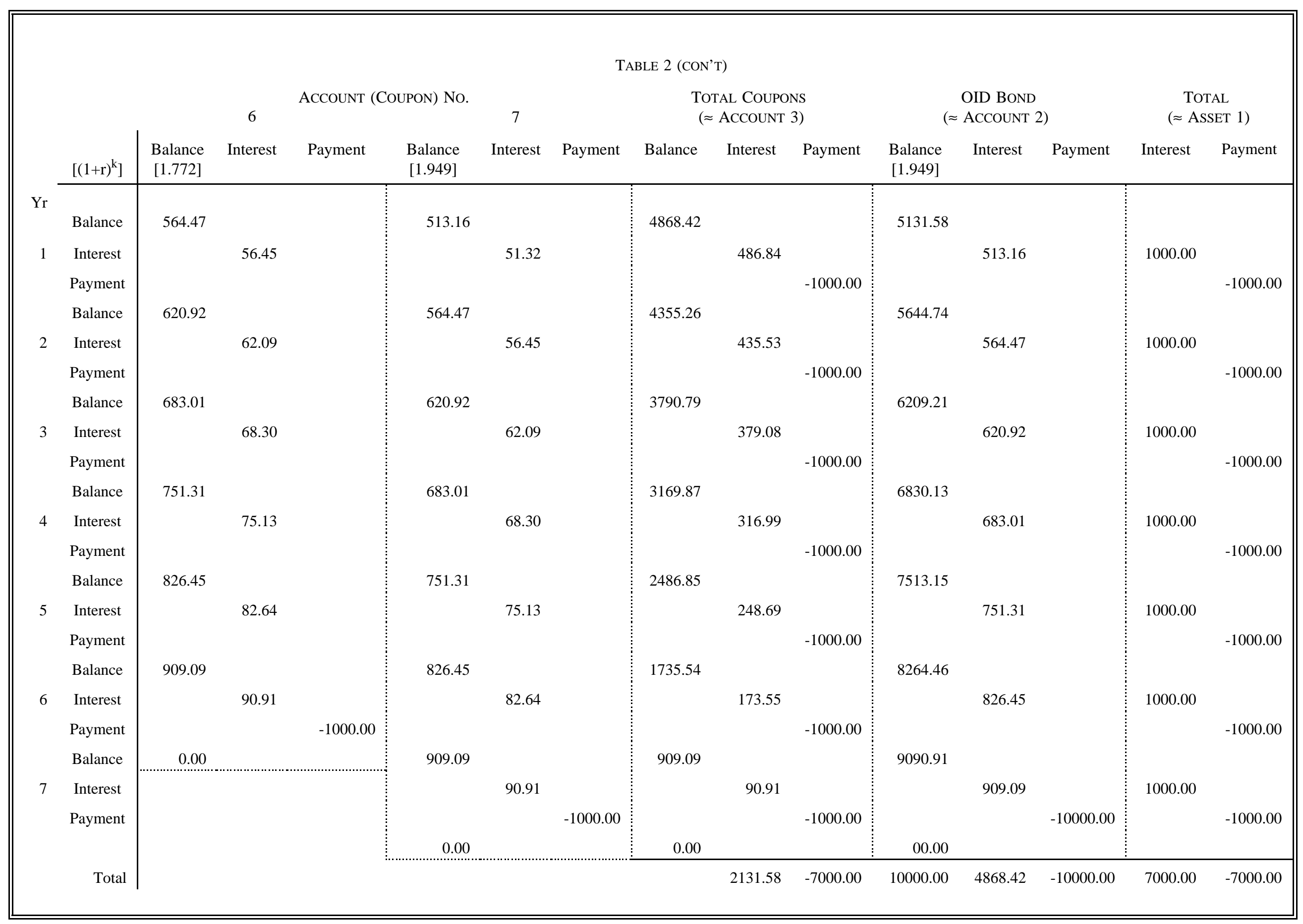




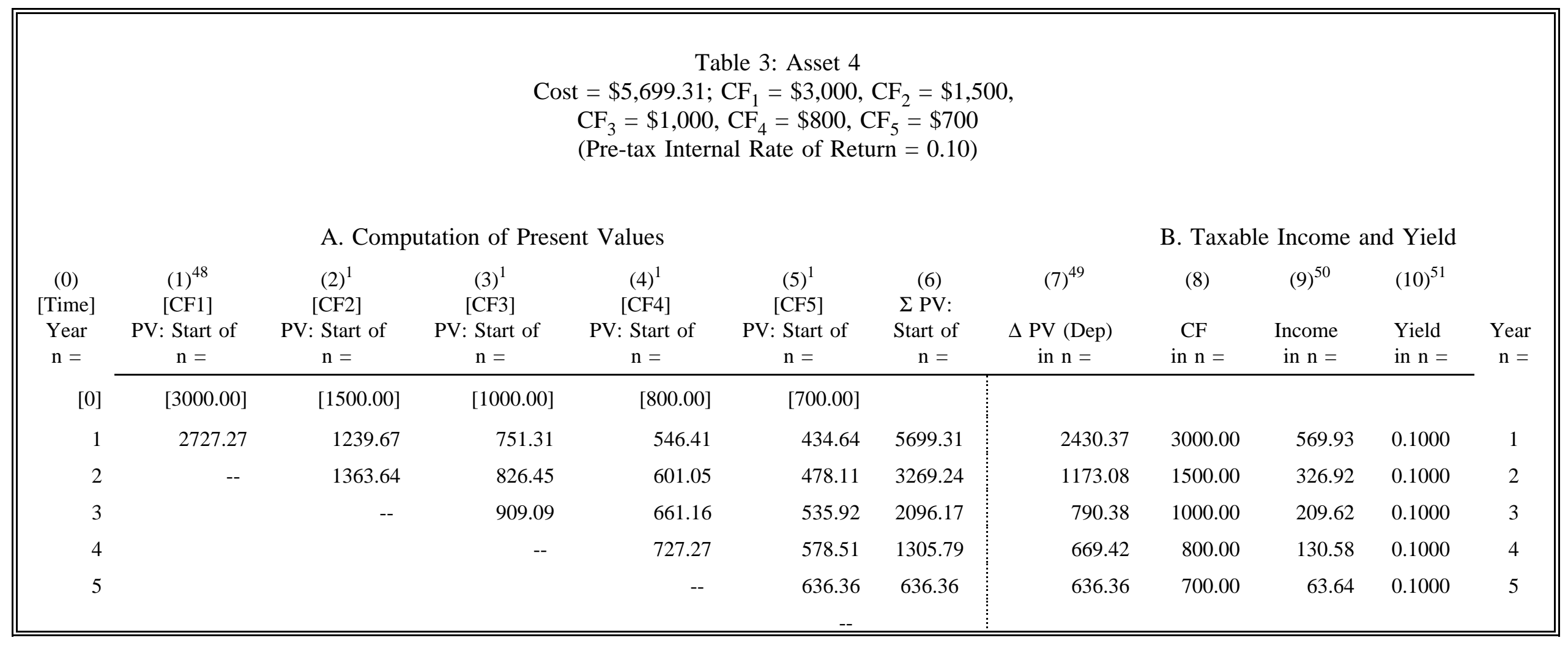

48 Each row $n=1, \ldots, 5$ reports the cash flow in column $j=1, \ldots, 5$, discounted at the internal rate of return to the start of year $n$, or

$$
\frac{C F_{j}}{(1+r)^{j-n+1}}, \text { for } j \geq n=1, \ldots, 5 .
$$

49 For each year $n$, the (sum of the) present values reported in Column (6), Row $n$, minus the sum of the present values reported in Column (6), Row $n+1$.

50 Column (8) minus Column (7).

51 Column (9) divided by Column (6). 
TABLE 4-1.

\begin{tabular}{|c|c|c|c|c|c|c|c|c|c|c|c|}
\hline \multirow[b]{3}{*}{ Year } & \multirow[b]{2}{*}{$(\mathrm{A} / \mathrm{B})$} & \multicolumn{4}{|c|}{$\begin{array}{l}\text { A1. ACCOUNT } 2 \\
\text { (@40\%) }\end{array}$} & \multicolumn{3}{|c|}{$\begin{array}{c}\text { B1. \$10,000 7-YEAR OID } \\
\text { BOND (@ 40\%) }\end{array}$} & \multirow[b]{2}{*}{$\begin{array}{c}(4) \\
\operatorname{PV}(3)(@ \mathrm{r}(1-\mathrm{t}))\end{array}$} & \multirow[b]{2}{*}{$\begin{array}{c}\text { (5) } \\
\mathrm{PV}(1) \stackrel{(@ \mathrm{r}(1-\mathrm{t}))}{ }\end{array}$} & \multirow[b]{2}{*}{$\begin{array}{c}(6) \\
(5)+\Sigma(4)\end{array}$} \\
\hline & & $\begin{array}{c}(1) \\
\text { Balance }\end{array}$ & $\begin{array}{c}(2) \\
\text { Interest }\end{array}$ & $\begin{array}{l}(3) \\
\text { Tax }\end{array}$ & $\begin{array}{c}(4) \\
\mathrm{PV}(@ \mathrm{r}(1-\mathrm{t}))\end{array}$ & $\begin{array}{l}(1) \\
\text { AIP }\end{array}$ & $\begin{array}{l}(2) \\
\text { OID }\end{array}$ & $\begin{array}{l}(3) \\
\text { Tax }\end{array}$ & & & \\
\hline & Initial & 5131.58 & & & & 5131.58 & & & & & \\
\hline 1 & Interest/OID & & 513.16 & & & & 513.16 & & & & \\
\hline & Tax & & & -205.26 & & & & -205.26 & -193.64 & & \\
\hline & Balance/ $/ \mathrm{PV}$ & 5439.48 & & & 5131.58 & 5644.74 & & & & 5325.23 & 5131.58 \\
\hline 2 & Interest/OID & & 543.95 & & & & 564.47 & & & & \\
\hline & Tax & & & -217.58 & & & & -225.79 & -200.95 & & \\
\hline & Balance/ $/ \mathrm{PV}$ & 5765.84 & & & 5131.58 & 6209.21 & & & & 5526.18 & 5131.58 \\
\hline 3 & Interest/OID & & 576.58 & & & & 620.92 & & & & \\
\hline & Tax & & & -230.63 & & & & -248.37 & -208.54 & & \\
\hline & Balance/ $/ \mathrm{PV}$ & 6111.80 & & & 5131.58 & 6830.13 & & & & 5734.71 & 5131.58 \\
\hline 4 & Interest/OID & & 611.18 & & & & 683.01 & & & & \\
\hline & Tax & & & -244.47 & & & & -273.21 & -216.40 & & \\
\hline & Balance/ $/ \mathrm{PV}$ & 6478.50 & & & 5131.58 & 7513.15 & & & & 5951.12 & 5131.58 \\
\hline 5 & Interest/OID & & 647.85 & & & & 751.31 & & & & \\
\hline & Tax & & & -259.14 & & & & -300.53 & -224.57 & & \\
\hline & Balance/ $/ \mathrm{PV}$ & 6867.21 & & & 5131.58 & 8264.46 & & & & 6175.69 & 5131.58 \\
\hline 6 & Interest/OID & & 686.72 & & & & 826.45 & & & & \\
\hline & Tax & & & -274.69 & & & & -330.58 & -233.04 & & \\
\hline & Balance/ $/ \mathrm{PV}$ & 7279.25 & & & 5131.58 & 9090.91 & & & & 6408.73 & 5131.58 \\
\hline 7 & Interest/OID & & 727.92 & & & & 909.09 & & & & \\
\hline & Tax & & & -291.17 & & & & -363.64 & -241.84 & & \\
\hline & Balance $/ \Sigma P V$ & 77716.00 & & & 5131.58 & 10000.00 & & & 6650.57 & 6650.57 & 5131.58 \\
\hline & & & & & & & 4868.42 & & 5131.58 & & 5131.58 \\
\hline
\end{tabular}


TABLE 4-2.

\begin{tabular}{|c|c|c|c|c|c|c|c|c|c|c|c|}
\hline \multirow[b]{3}{*}{ Year } & \multirow[b]{2}{*}{$(\mathrm{A} / \mathrm{B})$} & \multicolumn{4}{|c|}{$\begin{array}{l}\text { A2. ACCOUNT } 2 \\
\text { (@ 25\%) }\end{array}$} & \multicolumn{4}{|c|}{$\begin{array}{c}\text { B2. } \$ 10,000 \text { 7-YEAR OID } \\
\text { BOND (@ 25\%) }\end{array}$} & \multirow[b]{2}{*}{$\begin{array}{c}\stackrel{(5)}{ } \\
\mathrm{PV}(1) \stackrel{(@ \mathrm{r}(1-\mathrm{t}))}{ }\end{array}$} & \multirow[b]{2}{*}{$\begin{array}{c}(6) \\
(5)+\Sigma(4)\end{array}$} \\
\hline & & $\begin{array}{c}(1) \\
\text { Balance }\end{array}$ & $\begin{array}{l}(2) \\
\text { Interest }\end{array}$ & $\begin{array}{l}(3) \\
\text { Tax }\end{array}$ & $\begin{array}{c}(4) \\
\text { PV }(@ \mathrm{r}(1-\mathrm{t}))\end{array}$ & $\begin{array}{l}(1) \\
\text { AIP }\end{array}$ & $\begin{array}{l}(2) \\
\text { OID }\end{array}$ & $\begin{array}{l}(3) \\
\text { Tax }\end{array}$ & $\begin{array}{c}(4) \\
\mathrm{PV}(3) \\
(\text { (@r } \mathrm{r}(1-\mathrm{t}))\end{array}$ & & \\
\hline & Initial & 5131.58 & & & & 5131.58 & & & & & \\
\hline 1 & Interest/OID & & 513.16 & & & & 513.16 & & & & \\
\hline & Tax & & & -128.29 & & & & -128.29 & -119.34 & & \\
\hline & Balance/ $/ \mathrm{PV}$ & 5516.45 & & & 5131.58 & 5644.74 & & & & 5250.92 & 5131.58 \\
\hline 2 & Interest/OID & & 551.64 & & & & 564.47 & & & & \\
\hline & Tax & & & -137.91 & & & & -141.12 & -122.11 & & \\
\hline & Balance/ $/ \mathrm{PV}$ & 5930.18 & & & 5131.58 & 6209.21 & & & & 5373.03 & 5131.58 \\
\hline 3 & Interest/OID & & 593.02 & & & & 620.92 & & & & \\
\hline & Tax & & & -148.25 & & & & -155.23 & -124.95 & & \\
\hline & Balance/ $/ \mathrm{PV}$ & 6374.95 & & & 5131.58 & 6830.13 & & & & 5497.99 & 5131.58 \\
\hline 4 & Interest/OID & & 637.49 & & & & 683.01 & & & & \\
\hline & Tax & & & -159.37 & & & & -170.75 & -127.86 & & \\
\hline & Balance/ $/ \mathrm{PV}$ & 6853.07 & & & 5131.58 & 7513.15 & & & & 5625.85 & 5131.58 \\
\hline 5 & Interest/OID & & 685.31 & & & & 751.31 & & & & \\
\hline & Tax & & & -171.33 & & & & -187.83 & -130.83 & & \\
\hline & Balance/ $/ \mathrm{PV}$ & 7367.05 & & & 5131.58 & 8264.46 & & & & 5756.68 & 5131.58 \\
\hline 6 & Interest/OID & & 736.70 & & & & 826.45 & & & & \\
\hline & Tax & & & -184.18 & & & & -206.61 & -133.88 & & \\
\hline & Balance/ $/ \mathrm{PV}$ & 7919.58 & & & 5131.58 & 9090.91 & & & & 5890.56 & 5131.58 \\
\hline 7 & Interest/OID & & 791.96 & & & & 909.09 & & & & \\
\hline & Tax & & & -197.99 & & & & -227.27 & -136.99 & & \\
\hline & Balance/ $/ \mathrm{PV}$ & 8315.55 & . & & 5131.58 & 10000.00 & & & 6027.55 & 6027.55 & 5131.58 \\
\hline & TOTAL & & & & & & 4868.42 & & 5131.58 & & 5131.58 \\
\hline
\end{tabular}




\section{APPENDIX}

This appendix takes up three propositions in the text. (1) It shows that a sequence of $N$ equal periodic payments and a pure discount bond with redemption price $S$ and maturity $N$ will be equivalent to an $N$-year coupon bond with face amount $S$ if each payment equals the product of the bond's yield-to-maturity and $S$. (2) It illustrates algebraically the general equivalence between economic depreciation (using (2)) and accrual taxation (as in (1)). (3) It illustrates that taxation of a pure discount bond under I.R.C. $\S 1272(\mathrm{a})$ is equivalent to paying out of a bank account the taxes on the interest earned in the account, and that both produce valuation that is independent of the tax rate. The last, in effect, is a formal, discrete time proof of the Samuelson theorem for the special case of accrual taxation under $\S 1272$. The exposition makes use of several of the standard discrete time discounting functions, which may be found in any MBA level finance or corporate finance text. ${ }^{1}$

\section{THE STRIPPED BOND}

In discrete time the present value at date $k$ of a pure discount bond with redemption price $S$, maturity date $N>k$, and yield-to-maturity $r$, is

$$
\frac{S}{(1+r)^{N-k}}
$$

and it can be shown that the change in (A1) between periods $k$ and $k+1$ is given by

$$
r * \frac{S}{(1+r)^{N-k}} .
$$

(More generally, (A1) and (A1d) give the present value of any cash flow due in year $N$, and its rate of change as $k$ increases and the due date of the cash flow draws closer.)

Also at date $k$, the present value, discounted at rate $r$, of a constant stream of payments $C$ ending in year $N$, is

$$
\frac{C}{r}\left(1-\frac{1}{(1+r)^{N-k}}\right) .
$$

and the change in (A2) is given by

$$
\frac{-C}{(1+r)^{N-k}} .
$$

If we set $C$ equal to a coupon given by the product of the yield-to-maturity on, and the redemption price at maturity of, the bond, that is $C=r^{*} S$, then $S=C / r$, and (A1) becomes

1 The are also derived and collected, with specific reference to income taxation, in Sims, Introduction to Discounting: Discrete Time (2009). The observations here assume a flat "term structure" of interest rates. E.g., Brealy, Myers \& Allen, Principles of Corporate Finance 57-59, 629-31 (8th ed. 2006); see Bankman \& Klein, Accurate Taxation of Long-Term Debt: Taking Into Account the Term Structure of Interest, 44 Tax L. Rev. 335 (1989); Sims, Long Term Debt, The Term Structure of Interest and the Case for Accrual Taxation, 47 Tax L. Rev. 313 (1992). 
$\left(\mathrm{A} 1^{\prime}\right)$

$$
\frac{C}{r} * \frac{1}{(1+r)^{N-k}},
$$

and (A1d) becomes

$\left(A 1 d^{\prime}\right)$

$$
r * \frac{C}{r} * \frac{1}{(1+r)^{N-k}}=\frac{C}{(1+r)^{N-k}} .
$$

That is, the rates of change of the bond (A1d') and "the coupons" (A2d) are now equal but opposite in sign, so that in every period the increase in the value of the bond (A1) is exactly offset by a decrease in the value of the coupons (A2).

Although the treatment has evolved over time, the accrual of yield as given by (A1d) is the amount now annually included in income under $§ 1272(\mathrm{a})$ in respect of the bond. The amount taxed to the holder of a stream of equal payments varies in practice, but the procedure implied by Samuelson (1964) would be to include each payment in income, and subtract (as "economic" amortization) the annual decline in the value of the stream, as given by the absolute value of (A2d). ${ }^{2}$ That procedure produces income of

$$
C-\frac{C}{(1+r)^{N-k}}=C\left(1-\frac{1}{(1+r)^{N-k}}\right) .
$$

With our assumptions, then, three things follow from (A1d') and (A2d):

1. The income taxed in respect of the stream in each period, given by ( $\left.\mathrm{Ai}^{\prime}{ }^{\prime}\right)$, is equal to $r$ times its present value as of the beginning of each period, as given in (A2). So both the bond (A1) and the coupons (A2) are taxed on the accrual of yield to their respective present values at the beginning of each period.

2. The sum of the present values of the bond $\left(\mathrm{A1}^{\prime}\right)$ and coupons (A2) in every period is

$$
\frac{C}{r} * \frac{1}{(1+r)^{N-k}}+\frac{C}{r}\left(1-\frac{1}{(1+r)^{N-k}}\right)=\frac{C}{r}=S,
$$

the stated redemption price of the bond.

3. The amounts taxed to the bond (A1d') and coupons (Ai2') in every period is

$$
\frac{C}{(1+r)^{N-k}}+C\left(1-\frac{1}{(1+r)^{N-k}}\right)=C,
$$

which with the assumption $\mathrm{C}=\mathrm{r}^{*} \mathrm{~S}$ equals a coupon at rate $r$ on the bond.

\footnotetext{
2 As developed in the text, this (in effect) is also what would now be produced by the I.R.C. $\S 1286$, although the latter does so by directly imputing yield to each payment under $\S 1272$ (a).
} 
The same logic, assuming still that $C / r=S$, says that one bank account funded with (A1) that leaves all interest (at rate $r$ ) on deposit until $N$, and another funded with (A2), also earning interest at rate $r$ but subject to a periodic withdrawal of $C=s^{*} R$, will likewise be equivalent to the bond.

\section{The Equivalence OF ECONOMic DePRECIATION AND ACCRUAl TAXATION ${ }^{3}$}

Given a discount rate $r>-1$, an asset consisting of cash flows $\left\{C_{1}, C_{2}, \ldots C_{\mathrm{N}}\right\}$, can be valued as the sum of the present values of its cash flows, or

$$
V_{0}(r)=\sum_{j=1}^{N} \frac{C_{j}}{(1+r)^{j}} .
$$

More generally, the value after that date as of the end of any intervening period $k$ is the value of the remaining $n-k$ cash flows $\left\{C_{\mathrm{k}+1}, \ldots, C_{\mathrm{N}}\right\}$ discounted to the end of period $k$ (equivalently, the beginning of period $k+1)$, or

$$
V_{k}(r)=\sum_{j=k+1}^{N} \frac{C_{j}}{(1+r)^{(j-k)}},
$$

with $V_{\mathrm{N}}=0$.

Intuitively, the value of the asset in period $k+1$ would increase as the discounting period got shorter, but decrease by the receipt (and hence elimination) of $C_{\mathrm{k}+1}$. Taking into account both, the next period's value would be

$$
V_{k+1}(r)=(1+r) V_{k}-C_{k+1} .
$$

So the change in value from period $\mathrm{k}$ to $\mathrm{k}+1$ would be

$$
\begin{aligned}
V_{k}-V_{k+1} & =V_{k}-\left[(1+r) V_{k}-C_{k+1}\right] \\
& =-r V_{k}+C_{k+1} \equiv D_{k+1} .
\end{aligned}
$$

$D_{\mathrm{k}+1}$ represents economic depreciation of the asset in period $k+1$; it corresponds to the continuous depreciation function in Samuelson.

It follows that if in each period we include $C_{\mathrm{k}+1}$ in income, but allow a deduction for depreciation equal to $D_{\mathrm{k}+1}$ as given by (A3d), we tax

$$
C_{k+1}-D_{k+1}=C_{k+1}-\left(-r V_{k}+C_{k+1}\right)=r V_{k}
$$

But (A4) is just the accrual of yield (at rate $r$ ) on the asset's value at the beginning of period $k+1$. Thus, economic depreciation induces pure accrual taxation; the two are formally equivalent.

\footnotetext{
3 The material developed in A-II is based on Sims, Economic Depreciation and Invariant Valuation: A Constructive Proof of the Samuelson Theorem (2012, available at http://papers.ssrn.com/sol3/papers.cfm?abstract_id=2006557). Part A-III establishes a more restricted version of the Samuelson theorem than the version developed in that paper.
} 


\section{The Samuelson Theorem and Pure Discount Debt.}

To substantiate the Samuelson theorem is in effect to show that with taxes, and discounting at an after-tax rather than a pre-tax discount rate, both taxes and discounting disappear from the valuation of an asset. For both a perpetuity and a simple bank account on which interest is taxed as it accrues, the illustration is simple.

Perpetuity. With a discount rate $r$, the present value of a perpetual periodic payment $C$ is $C / r$. If each payment is taxed at rate $t$, however, the payment is reduced to $C^{*}(1-t)$. But with pretax discount rate $r$ and tax rate $t$, the after-tax discount rate becomes $r^{*}(1-t)$, and taking both changes into account the perpetuity is now worth

$$
\frac{C^{*}(1-t)}{r^{*}(1-t)}=\frac{C}{r}
$$

So its value with taxes doesn't change. The effect of taxes on cash-flow and discounting exactly offset. $^{4}$

Bank account. The perpetuity has two simplifying virtues, however, one being that it implicitly assumes that the taxes are paid out of the perpetuity. The other is that it does not appreciate or depreciate from period to period, a virtue shared by few other assets. That virtue sweeps under the rug the dependence of the analysis on the way in which changes in value are taken into account for purposes of taxation. Nevertheless, an equally simple case is that of a bank account on which interest is left to accrue, except for withdrawals needed to pay the taxes themselves. For an account with initial endowment $E$ earning interest at rate $r$, the pre-tax compound growth in the account in $N$ years is

$$
E^{*}(1+r)^{N},
$$

but if taxes are levied on and paid out of the accrued interest each year, at rate $t$ (in the amount $t r)$, the rate of growth will be $r-r t=r(1-t)$, so that the compound growth will be reduced to

$$
E^{*}[1+r(1-t)]^{N}
$$

If, however, the balance at date $N$ (or at any intervening time) is discounted to present value, the discount rate (taking into account taxes) will be $r(1-t)$ and the discount factor for $N$ years will be $[1+r(1-t)]^{\mathrm{N}}$, so that the discounted value of that balance will just be

$$
E^{*} \frac{[1+r(1-t)]^{N}}{[1+r(1-t)]^{N}}=E
$$

So in this case, too, it is easy to see that the account value is unaffected, and the intuition is identical to that with the perpetuity. In both cases, moreover, it is straightforward to show that the results hold in the presence of time-varying tax and interest rates.

Pure Discount Bond. It is more difficult when the asset changes in value and, in contrast with the simple bank account, the taxes are satisfied with other resources. For a pure discount

\footnotetext{
4 See Interview with James F. Strnad, II, 14 ABA Tax Section Newsletter 9, 10 (1994).
} 
bond taxed under $\S 1272(a)$, interest accrues based on the pre-tax change in its value (its "adjusted issue price" in statutory parlance). So it is necessary to show that, at any point in time, the adjusted issue price together with the sum of all taxes paid to that point in time, when discounted at an after tax discount rate, equal the asset's "issue price", the price for which it initially sold. Stated slightly differently, it amounts to showing that if at any time the asset were sold for its adjusted issue price, the after-tax discounted value of all cash flows from the asset (including taxinduced cash flows) will equal its issue price.

Denoting the issue price of the bond by $V_{0}$, the discount accrued in the first period would be $r V_{0}$, tax on that accrual would be $\operatorname{tr} V_{0}$, and the adjusted issue price after one period would be $V_{0}(1+r)$. Discounting the adjusted issue price minus the taxes paid for one period at an after-tax discount rate produces

$$
\frac{V_{0}(1+r)}{[1+r(1-t)]}-\frac{t r V_{0}}{[1+r(1-t)]}
$$

Given the adjustment to the issue price required by $\$ 1272(\mathrm{a})$, the discount accrued in the second period would be $r V_{0}(1+r)$, tax on that accrual would be $\operatorname{tr} V_{0}(1+r)$, and the adjusted issue price after the second period would be $V_{0}(1+r)^{2}$. Discounting those to the issue date (for two periods) produces

$$
\frac{V_{0}(1+r)^{2}}{[1+r(1-t)]^{2}}-\frac{\operatorname{tr} V_{0}(1+r)}{[1+r(1-t)]^{2}} .
$$

But the present value as of the issue date of all cash flows must also include the first period's taxes, discounted for one period, so it is

$$
\begin{gathered}
\frac{V_{0}(1+r)^{2}}{[1+r(1-t)]^{2}}-\frac{t r V_{0}}{[1+r(1-t)]}-\frac{t r V_{0}(1+r)}{[1+r(1-t)]^{2}} \\
=\frac{V_{0}(1+r)^{2}}{[1+r(1-t)]^{2}}-t r V_{0} \sum_{j=1}^{2} \frac{(1+r)^{j-1}}{[1+r(1-t)]^{j}} .
\end{gathered}
$$

Proceeding recursively it is apparent that, as of the end of period $n$, the present value of the adjusted issue price minus all taxes paid to that point would be

$$
\frac{V_{0}(1+r)^{n}}{[1+r(1-t)]^{n}}-\operatorname{tr} V_{0} \sum_{j=1}^{n} \frac{(1+r)^{j-1}}{[1+r(1-t)]^{j}} .
$$

With that expression, the Samuelson theorem is equivalent to the claim that

$$
V_{0}=\frac{V_{0}(1+r)^{n}}{[1+r(1-t)]^{n}}-\operatorname{tr} V_{0} \sum_{j=1}^{n} \frac{(1+r)^{j-1}}{[1+r(1-t)]^{j}},
$$

or, multiplying through by $[1+r(1-t)]^{\mathrm{n}}$ and eliminating $V_{0}$, that 


$$
[1+r(1-t)]^{n}=(1+r)^{n}-t * r \sum_{j=1}^{n}(1+r)^{j-1}[1+r(1-t)]^{n-j}
$$

PROOF (BY INDUCTION): Suppose that's true. Then, multiplying both sides by [1+r*(1-t)] produces

$$
\begin{gathered}
{[1+r(1-t)]^{n+1}=[1+r-r t]\left[(1+r)^{n}-t * r \sum_{j=1}^{n}(1+r)^{j-1}[1+r(1-t)]^{n-j}\right]} \\
=(1+r)^{n+1}-t * r *(1+r)^{n}-t * r \sum_{j=1}^{n}(1+r)^{j-1}[1+r(1-t)]^{n+1-j} \\
=(1+r)^{n+1}-t * r \sum_{j-1}^{n+1}(1+r)^{j-1}[1+r(1-t)]^{n+1-j}
\end{gathered}
$$

